AT - TADBIR

JURNAL ILMIAH MANAJEMEN

Homepage: ojs.uniska.ac.id/attadbir

\title{
Apakah Instagram lebih penting dibandingkan Inovasi Produk Dan Citra Merek Terhadap Minat Beli Produk Kuliner? Studi Kasus: Kaum Milenial di daerah Jakarta Selatan
}

\author{
Fachrul Husain Habibie $^{\mathbf{1}^{*} \text {, Amalia Mustika }}{ }^{1}$, Deivy $\mathrm{Z}$ Nasution ${ }^{1}$, Willy Arafah ${ }^{2}$, Nurbaeti $^{1}$ \\ ${ }^{1}$ Sekolah Tinggi Pariwisata Trisakti Jakarta \\ ${ }^{2}$ Universitas Trisakti \\ e-mail: fachrul@stptrisakti.ac.id
}

\begin{abstract}
In the current era of globalization and the Covid-19 pandemic, it is not only product innovation and brand image that need to be considered but how a product is known by the public, especially millennials, thereby increasing their buying interest. This study aims to determine which influence is the highest among Instagram, product innovation and brand image on buying interest on buying interest in culinary products among millennials in South Jakarta. The locations chosen in this study were 5 (five) restaurants, namely Mbok Ndoro, Blok M Space, Gordi HQ, Lesehan Restaurant, Kadai Mak Ciak and Head Manyung Bu Fat. The method used in this study is a quantitative explanatory method because this study explains the relationship between the variables that affect the researcher's hypothesis. The results of this study indicate that the influence of Instagram is greater than product innovation and brand image of culinary products for millennials during the current Covid 19 pandemic at Kedai Makan South Jakarta. It is hoped that culinary business traders need to immediately create an Instagram account in addition to increasing the variety of their products, it is important because when people use Instagram a lot to find information on various products including culinary products.
\end{abstract}

Keywords: Instagram, Product Innovation, Culinary Product Brand Image, Buying Interest

\begin{abstract}
Abstrak
Pada era globalisasi dan pandemic Covid 19 saat ini bukan hanya inovasi produk dan citra merek yang perlu diperhatikan tapi bagaimana suatu produk dikenal oleh masyarakat khususnya kaum milenial sehingga meningkatkan minat beli mereka. Penelitian ini bertujuan untuk mengetahui pengaruh mana yang tertinggi diantara instagram, inovasi produk dan citra merek terhadap minat beli terhadap minat beli produk kuliner pada kaum milinial di Jakarta Selatan. Lokasi yang dipilih pada penelitian ini adalah 5 (lima) kedai makan yaitu Mbok Ndoro M Bloc Space, Gordi HQ, Rumah Makan Lesehan, Kadai Mak Ciak dan Kepala Manyung Bu Fat. Metode yang digunakan dalam penelitian ini adalah metode kuantitatif eksplanatori karena penelitian ini menjelaskan hubungan antara variabel-variabel yang mempengaruhi hipotesis peneliti. Hasil penelitian ini menunjukkan bahwa pengaruh instagram lebih besar dibandingkan dengan inovasi produk dan citra merek produk kuliner bagi kaum milenial pada saat pandemi Covid 19 saat ini di Kedai Makan Jakarta Selatan. Diharapkan pedagang usaha kuliner perlu segera membuat akun istagram selain memperbanyak variasi produknya, penting dikarenakan pada saat masyarakat banyak menggunakan instagram untuk mencari informasi berbagai produk termasuk produk kuliner.
\end{abstract}

Kata Kunci: Instagram, Inovasi Produk, Citra Merek Produk Kuliner, Minat Beli 


\section{PENDAHULUAN}

Pada era globalisasi dan pandemic Covig 19 saat ini internet dapat memudahkan hidup seseorang. Dengan adanya internet seseorang bisa mencari informasi ataupun berkomunikasi dengan mudah. Dalam dunia digital seperti saat ini internet bisa menghubungkan berbagai kalangan masyarakat dengan status sosial yang berbeda tanpa harus bertatap muka, berkomunikasi jauh terasa lebih dekat walaupun berada di belahan dunia yang berbeda. Pemanfaatan internet pun semakin pesat, media internet tidak lagi hanya digunakan sebagai media komunikasi tetapi sebagai sarana informasi dan promosi di berbagai bidang seperti dunia bisnis, entertainment, pendidikan, pariwisata, dan pergaulan sosial. Seiring dengan perkembangan internet, semakin beraneka ragam pula media sosial yang ada, seperti Facebook, Instagram, Twitter, Whatsapp, Youtube, Tiktok, dan lain-lain. Penelitian yang dilakukan oleh Habibie, et al (2021) menunjukkan bahwa instagram sangat berpengaruh terhadap usaha yang sedang dilaksanakan karena dengan Instagram, pelaku usaha dapat melakukan pemasaran produk dengan tepat karena produk yang akan dijual dapat diperkenalkan pada semua orang.

Penelitian yang dilakukan oleh Suparnoto \& Setiobudi (2020), menunjukkan bahwa promosi media sosial Instagram berpengaruh terhadap minat beli. Hal ini karena semakin banyaknya pengguna media sosial instagram, hal ini dapat memberikan peluang kepada peluang usaha baik barang ataupun jasa dalam memasarkan produk mereka. Kemudian penelitian yang dilakukan oleh Hartawan, et al (2021), media sosial instagram sangat mempengaruhi minat beli karena banyak orang menggunakan media sosial instagram, dimana sebanyak 60 juta orang di Indonesia menggunakan media sosial instagram, oleh karena itu banyak pelaku usaha mempromosikan produknya di instagram karena dapat menunjukkan foto/video dari produknya beserta deskripsi singkat yang dapat digunakan untuk menjelaskan produk yang ditawarkan.

Strategi pemasaran melalui media sosial instagram adalah penelitian yang dilakukan oleh Untari \& Fajariana (2018), hasilnya menunjukkan bahwa setelah pelaku usaha melakukan promosi dengan instagram mengalami peningkatan penjualan karena instagram merupakan internet marketing, dengan banyaknya pengguna aktif instagram, kekuatan dan jangkauan instagram memang sangat kuat yang memuat foto dan video yang memberi audiens informasi menarik dengan cara baru dan unik. Para pelaku usaha dapat menggunakan fitur instagram ads ataupun konten-konten instagram yang menarik sehingga dapat membuat orang-orang tertarik terhadap produk mereka.

Pemanfaatan media sosial sebagai media promosi ditunjukkan oleh penelitian yang dilakukan Hanief \& Jepriana (2019) bahwa kegiatan usaha pada masa sekarang khususnya di bidang kuliner tidak lepas dari pemanfaatan media instagram. berbagai macam produk makanan dan minuman yang ditawarkan oleh pelaku usaha dikemas sedemikian rupa agar menarik minat para calon pembeli. Ketatnya dunia persaingan usaha membuat para pelaku usaha untuk lebih berinovasi kepada produk yang ditawarkan, produk yang tidak hanya memiliki cita rasa yang lezat tetapi juga memiliki ciri khas untuk menarik konsumen. Ciri khas tersebut merupakan modal untuk mengenalkan brand usaha mereka kepada masyarakat luas.

Selain instagram sebagai promosi memperkenalkan produk untuk 
meningkatkan minat beli konsumen, inovasi produk juga dapat meningkatkan minat beli konsumen karena inovasi produk akan meningkatkan nilai tambah produk, dan inovasi akan menciptakan produk baru yang dapat memberikan solusi yang lebih baik atas permasalahan yang dihadapi konsumen. Inovasi produk berpengaruh signifikan terhadap minat beli konsumen, penelitian ini dilakukan oleh Maulana \& Alisha (2020), menunjukkan bahwa dengan inovasi produk menjadi pertimbangan yang sangat penting bagi konsumen untuk menentukan minat belinya, konsumen akan melihat dan mencari informasi lebih detail mengenai produk pilihan mereka. Hal ini akan membuat inovasi pada suatu produk menjadi salah satu yang dikenali pelanggan sehingga dapat meningkat volume penjualan sesuai yang diharapkan perusahaan.

Penelitian yang dilakukan Putra \& Kusumadwi (2019) menunjukkan bahwa inovasi produk memberikan pengaruh positif terhadap niat beli konsumen karena semakin baik inovasi produk yang dimiliki berakibat positif pada niat beli ulang konsumen untuk membeli. Dengan inovasi produk dapat menghasilkan produk baru yang kreatif yang sesuai dengan keinginan konsumen akan memberikan respon positif terhadap niat beli ulang konsumen.

Penelitian tentang pengaruh inovasi produk terhadap minat beli juga dilakukan oleh Suyaman, et al (2021), hasilnya menunjukkan inovasi produk berpengaruh positif terhadap minat beli, semakin tinggi inovasi produk maka akan semakin tinggi pula minat beli dan juga konsumen yang inovatif mampu mendorong konsumen untuk mencoba produk baru dengan teknologi baru, ingin mempelajari pengetahuan baru yang berimbas pada minat beli.

Selain inovasi produk, citra merek juga merupakan faktor yang menentukan minat beli konsumen. Untuk memahami sekaligus mempengaruhi keputusan pembelian, maka perusahaan harus memiliki citra merek yang kuat di benak konsumen. Penelitian pengaruh citra merek terhadap minat beli konsumen dilakukan oleh Antonius \& Sugiharto (2013), menunjukkan bahwa citra merek berpengaruh signifikan terhadap minat beli konsumen karena perusahaan yang berhasil membangun merek yang kuat akan memiliki nilai tambah dari perusahaan lain, keberadaan merek dianggap sebagai pilar bisnis sehingga dapat menarik minat konsumen untuk memakai produk tersebut. Setiap merek yang ditawarkan memiliki ciri khas sendiri yang membedakan dengan produk pesaing.

Selanjutnya penelitian yang dilakukan oleh Fauziah \& Mubarok (2019) menunjukkan citra merek berpengaruh signifikan terhadap minat beli, karena suatu merek apabila posisinya sudah kuat, akan memudahkan perusahaan dalam memenangkan persaingan yang ada di pasar, citra merek produk sangatlah penting agar dapat mempertahankan dan bahkan dapat meningkatkan minat beli konsumen.

Tujuan penelitian ini adalah untuk mengetahui pengaruh media sosial instagram, inovasi produk dan citra merek terhadap minat beli kaum milenial pada produk kuliner di Jakarta Selatan. Peneliti mengambil tema ini karena instagram merupakan media sosial yang paling banyak penggunanya terutama kaum milenial daripada facebook dan twitter, karena instagram merupakan media sosial yang efektif dan efisien untuk mempromosikan produk kuliner agar meningkatkan minat beli konsumen khususnya kaum milenial. Kemudian peneliti mengambil variabel inovasi produk karena saat ini banyak kaum milenial 
sangat berminat terhadap produk kuliner yang baru dan kreatif serta kekinian yang sesuai dengan jamannya, maka banyak para pelaku usaha juga menciptakan inovasi produk kuliner dengan menciptakan produk kuliner yang baru dengan teknologi baru akan meningkatkan minat beli kaum milenial. Selanjutnya peneliti mengambil variabel citra merek karena kaum milenial saat ini pun memilih suatu produk kuliner dengan merek yang sudah dikenal atau merek yang ternama, karena merek yang yang sudah dikenal biasanya dapat mempertahankan kualitas produk dan pelayanan yang baik yang tidak mengecewakan kaum milenial sehingga dapat meningkatkan minat beli kaum milenial.

\section{TINJAUAN PUSTAKA}

\section{Sosial Media Instagram}

Instagram adalah sebuah aplikasi yang digunakan untuk membagikan foto dan video. Instagram merupakan bagian dari facebook yang memungkinkan temanteman di akun facebook kita mengikuti atau mem-follow akun instagram kita. Semakin populernya instagram sebagai aplikasi yang digunakan untuk membagi foto membuat banyak pengguna yang terjun ke bisnis online turut mempromosikan produkproduknya lewat instagram. Media sosial instagram adalah suatu alat penyampaian pesan untuk bisa berkomunikasi dengan khalayak secara luas dengan saling berbagi foto atau video, yang didalamnya juga terdapat fitur-fitur lain seperti DM (direct message), comment, love, dan lain-lain (Nisrina, 2015).

Berikut beberapa fitur yang akan ditemukan dalam instagram yang juga populer pada kebanyakan platform media sosial menurut lainnya (Diamond, 2015): (1) Foto dan video, pengguna instagram dapat memilih foto dan video yang akan di upload dari galeri atau album atau bisa dapat langsung menggunakan camera yang tersedia pada fitur tersebut; (2) Caption, tulisan atau keterangan yang berkaitan dengan foto atau video yang di unggah; (3) Komentar, terletak di bawah foto atau video, tepatnya di bagian tengah yang berfungsi untuk mengomentari postingan atau unggahan foto dan video yang dirasa menarik; (4) Hashtags, tanda pagar pada instagram memudahkan pengguna untuk mengelompokkan foto atau video yang diunggah agar mudah menemukan foto atau video sesuai dengan tema atau gambar yang diinginkan; (5) Like, apabila pengguna instagram menyukai unggahan foto atau video akun, maka dapat memberi like dengan menekan emoticon berbentuk love; (6) Explore, pengguna dapat melihat foto dan video dari unggahan dari akun yang diikuti atau disukai oleh orang yang diikuti pengguna tersebut; (7) Instagram story, memungkinkan pengguna instagram untuk mengupload foto maupun video dengan durasi 15 detik; (8) Live instagram, memungkinkan penggunanya untuk melakukan siaran langsung terkait aktivitas yang tengah dijalani; (9) Direct Message (DM), memungkinkan pengguna instagram untuk saling mengirim pesan secara private. (10) Geotagging, memasukan lokasi foto yang akan diunggah ke halaman utama.

\section{Inovasi Produk}

Inovasi merupakan penerapan hal-hal yang baru dalam suatu pelaksanaan tugas sebagai penerapan pengetahuan; hal-hal baru dalam inovasi dapat berupa ide, praktik, proses, pelayanan, ideologi, strategi bisnis atau objek; inovasi merupakan suatu perubahan dan atau berimplikasi perubahan sebagai akibat dari penerapan hal-hal baru (Lao, 2020).

Inovasi tidak hanya terbatas pada pengembangan produk-produk atau jasa- 
jasa baru. Inovasi juga termasuk pada pemikiran bisnis baru dan proses baru. Inovasi juga dipandang sebagai mekanisme perusahaan untuk beradaptasi dalam lingkungan yang dinamis. Oleh sebab itu maka perusahaan diharapkan menciptakan pemikiran-pemikiran baru, gagasan baru yang menawarkan produk inovatif serta memberikan pelayanan yang memuaskan bagi pelanggan. Inovasi semakin memiliki arti penting bukan saja sebagai suatu alat untuk mempertahankan kelangsungan hidup perusahaan melainkan juga untuk unggul dalam persaingan (Mayasari et al, 2021; Sinurat et al, 2017).

Inovasi produk diperlukan untuk memenuhi permintaan pasar, diikuti dengan terwujudnya daya saing perusahaan. Inovasi produk yang dikembangkan akan dapat meningkatkan kemampuan dari perusahaan untuk menghasilkan produk yang berkualitas. Perusahaan sebaiknya mampu meningkatkan kemampuan pengembangan produk yang telah dilakukan dengan tujuan produk yang dihasilkan memiliki potensi yang dapat dikembangkan untuk inovasi berkelanjutan, serta dengan terciptanya inovasi khususnya pada segi produk maka akan mendorong perusahaan dalam mewujudkan suatu nilai atas daya saing yang unggul (Widiarta et al, 2020).

Inovasi produk berkaitan dengan salah satu pengembangan suatu produk atau sebuah hal baru yang ditemukan, hal ini dilakukan agar konsumen tidak bosan dengan produk lama yang dihasilkan. Inovasi yang dilakukan atas produk oleh perusahaan dianggap dapat menghilangkan perasaan jenuh atau kebosanan konsumen atas pilihan produk oleh konsumen yang cenderung kurangnyakeberagaman serta tidak mempunyai keunikan. Dengan inovasi yang dilakukan industri atau perusahaan, akan memberikan nilai tambah terhadap produk yang dimiliki sehingga harapan konsumen akan terpenuhi. Salah satu manfaat dari inovasi bertujuan mempercantik produk sehingga lebih menarik bagi para konsumen (Dachi, 2020).

\section{Citra Merek}

Merek atau cap adalah suatu tanda atau simbol yang memberikan identitas suatu barang/jasa tertentu yang dapat berupa kata-kata, gambar atau kombinasi keduanya. Merek merupakan salah satu faktor penting dalam kegiatan pemasaran karena kegiatan memperkenalkan dan menawarkan produk atau jasa tidak terlepas dari merek yang dapat diandalkan. Merek adalah asset yang menciptakan value bagi pelanggan dengan meningkatkan kepuasan dan menghargai kualitas (Gifani et al, 2017).

Citra merek menjadi hal yang sangat penting diperhatikan perusahaan, melalui citra merek yang baik, maka dapat menimbulkan nilai emosional pada diri konsumen, dan akan timbul perasaan positif (positive feeling) pada saat membeli atau menggunakan suatu merek. Sebaliknya apabila suatu merek memiliki citra (image) yang buruk dimata konsumen, kecil kemungkinan konsumen untuk loyal terhadap produk tersebut (Rizal et al, 2019).

Citra merek dapat diartikan sebagai sebuah istilah, nama, logo, tanda, dan desain, serta untuk mengindentifikasi produk dan jasa yang diproduksi dan dijual oleh salah satu penjual maupun vendor serta untuk mencari tahu perbedaan antara pesaing. Citra merek merupakan suatu produk dan jasa memiliki dimensi yang membandingkan merek yakni membandingkan produk yang dimiliki dengan barang ataupun jasa lain yang dirancang guna memenuhi kebutuhan yang sama (Yanto et al, 2020). 
Kunci utama perusahaan untuk dapat bertahan dalam lingkungannya dan persaingan yang secara pasti adalah merek. Salah satu yang dapat digunakan untuk membangun merek yang baik ialah dengan melakukan inovasi produk, memunculkan ciri khas produk dibanding produk pesaing akan meningkatkan daya saing suatu produk. Merek memegang peranan sangat penting, salah satunya adalah menjembatani harapan konsumen pada saat perusahaan menjanjikan sesuatu kepada konsumen. Merek merupakan identitas sebuah produk yang dijadikan sebuat alat ukur apakah produk itu baik dan berkualitas. Konsumen melihat sebuah merek sebagai bagian yang paling penting dalam sebuah produk dan merek dapat menjadi sebuah nilai tambah dalam produk tersebut (Purwanti et al, 2020).

\section{Minat Beli}

Minat beli adalah sesuatu yang timbul setelah menerima rangsangan dari produk yang dilihatnya, lalu muncul keinginan untuk membeli dan memilikinya (Mustika et al, 2021). Model yang relevan untuk digunakan sebagai alat ukur minat beli adalah model AIDA yang merupakan akronim dari attention, intention, desire, action. Tahap-tahap pengukuran menggunakan AIDA yaitu (Rehman et al, 2014): (1) Awareness (kesadaran), pada tahap ini konsumen mulai timbul kesadarannya terhadap suatu produk sebelum terjadinya pembelian; (2) Interest (ketertarikan), tahap ini terjadi ketika perhatian konsumen sudah tertuju terhadap suatu produk, maka muncul ketertarikan terhadap suatu produk; (3) Desire (keinginan), tahap ini adalah tahapan memberikan penawaran yang menimbulkan keinginan atau hasrat konsumen untuk membeli suatu produk; (4) Action (tindakan), ini adalah tahap terakhir yaitu tahap dimana konsumen sudah mengambil tindakan untuk mulai melakukan pembelian terhadap produk.

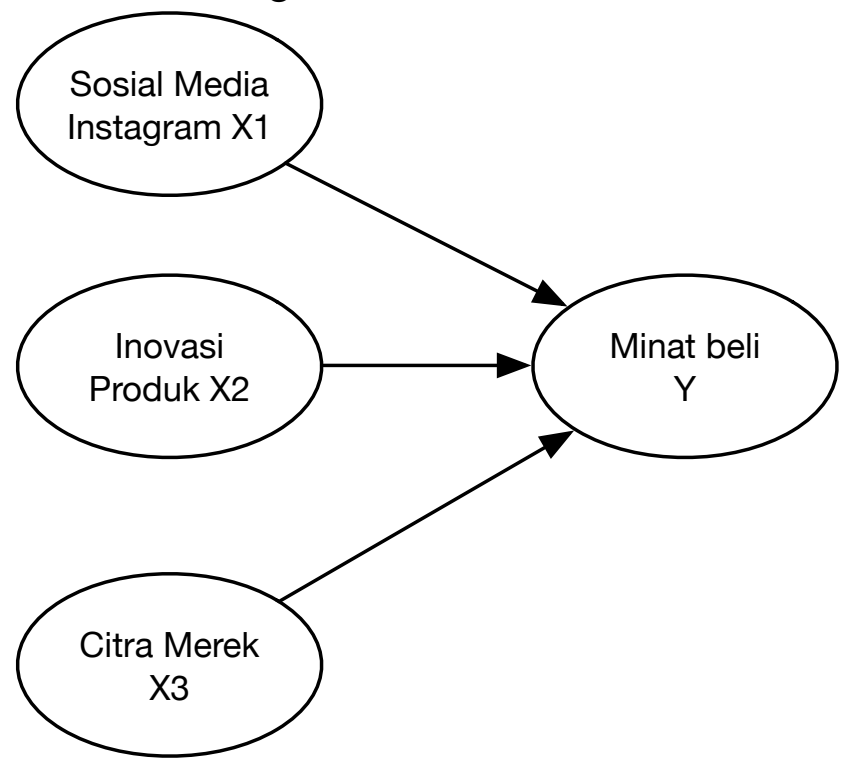

Gambar 1. Kerangka Hipotesis

\section{METODE PENELITIAN}

Jenis Penelitian

Metode yang digunakan dalam penelitian ini adalah metode kuantitatif eksplanatori karena penelitian ini menjelaskan hubungan antara variabelvariabel yang mempengaruhi hipotesis peneliti. 


\section{Lokasi Penelitian}

Lokasi yang dipilih pada penelitian ini adalah Jakarta Selatan meliputi 5 (lima) kedai makan yaitu Mbok Ndoro M Bloc Space, Gordi HQ, Rumah Makan Lesehan, Kadai Mak Ciak dan Kepala Manyung Bu Fat.

\section{Populasi dan sampel}

Sampel berjumlah sejumlah 100 responden karena menurut Sugiyono (2017) bahwa jumlah batas minimal yang harus diambil oleh peneliti yaitu sebanyak 30 sampel, semakin besar sampel yang ada adalah semakin baik.

\section{MetodePengumpulan data}

Metode pengumpulan data dengan menyebarkan kuisioner dengan skala likert. Populasi yang digunakan dalam penelitian ini adalah masyarakat yang berdomisili di wilayah Jakarta Selatan.

\section{Analisis Data}

Sesuai dengan tujuan penelitian, untuk mengetahui pengaruh dari masing-masing variabel, penelitian ini menggunakan analisis regresi berganda.

\section{HASIL DAN PEMBAHASAN}

Hasil

Karakteristik Responden

Distribusi karakteristik responden yang disajikan pada Tabel 1 dapat dijelaskan sebagai berikut. Berdasarkan jenis kelamin responden diatas menunjukkan bahwa yang paling banyak merespon kuesioner yang diberikan adalah yang berjenis kelamin perempuan sebesar $80 \%$ dan berjenis kelamin laki-laki sebesar 20\%. Hal ini bermakna bahwa saat ini dominal perempuan banyak memanfaatkan smartphone untuk mencari informasi melalui internet tentang produk kuliner.
Berdasarkan usia responden diatas menunjukkan bahwa 21-25 tahun yang dominan merespon kuesioner dengan besaran 53\%, kemudian usia 15-20 tahun sebesar 29\%, usia $26-3012 \%$ dan diatas 30 tahun $6 \%$. Hal ini berarti bahwa saat ini kaum melenial telah menjadikan sosial media sebagai referensi ketika memilih kuliner yang ada.

Berdasarkan pekerjaan responden diatas menunjukkan bahwa dominan pekerjaan responden adalah pelajar/ mahasiswa sebayak 73\%, kemudian kayawan $17 \%$ wiraswasta $6 \%$ dan yang belum bekerja dan lai-lain sebesar $3 \%$ dan $1 \%$. Hal ini menunjukkan bahwa pada saat on dominan yang menggunakan social media untuk mendapatkan informasi adalah masyarakat melinial.

\section{Uji Validitas dan Reliabilitas}

Hasil uji validitas menunjukkan seluruh indikator variabel instagram, inovasi produk dan citra merek serta minat beli menunjukkan r-hitung lebih besar dari rtabel 0.1638. Dari hasil tersebut maka seluruh indikator seluruh variabel adalah valid. Adapun dari hasil uji reliabilitas menunjukkan bahwa seluruh variabel adalah reliabel karena nilai Cronbach's Alpha lebih besar dari 0,60.

\section{Uji Asumsi Klasik}

Pengujian asumsi klasik pada Tabel 2 dilakukan sebelum melakukan pengujian hipotesis untuk memastikan bahwa data yang digunakan telah sesuai dengan kaidah pengujian regresi linear berganda. Pertama, hasil uji normalitas menunjukkan bahwa nilai signifikansi asymp.sig (2-tailed) sebesar 0,355 lebih besar dari 0,05, maka dapat disimpulkan bahwa data berdistribusi normal.

Pada pengujian kedua, hasil uji multikolinearitas menunjukkan model 
regresi dalam penelitian ini tidak terjadi atau bebas multikolinearitas, karena nilai tolerance untuk semua variabel lebih dari 0,10 dan nilai VIF kurang dari 10 .

Pada pengujian ketiga, Hasil uji heteroskedastisitas menunjukkan titik-titik data menyebar diatas dan di bawahn atau disekitar angka 0 dan tidak hanya mengumpul diatas atau di bawah saja. Penyebaran titik-titik data tidak membentuk pola gelombang melebar kemudian menyempit dan melebar kembali. Dengan demikian model regresi ini tidak terjadi masalah heteroskedastitas.

Pada pengujian keempat, Hasil uji autokorelasi diketahui nilai Durbin-Watson adalah sebesar 2,015. Selanjutnya nilai ini akan dibandingkan dengan nilai tabel durbin Watson pada signifikasi 5\%. Adapun jumlah variabel bebas adalah 3, sementara jumlah sampel atau $=100$. Berdasarkan nilai tersebut maka ditemukan nilai dL sebesar 1,6131 dan dU sebesar 1,7364. Durbin Watson sebesar 2,051 lebih besar dari batas atas (dU) yaitu 1,7364 dan kurang dari (4 dU) $4-1,7364=2,2636$. Maka model regresi ini tidak terdapat masalah atau gejala autokorelasi.
Hasil pengujian hipotesis yang ditunjukkan pada Tabel 3 dapat dijelaskan sebagai berikut. Untuk variabel instagram memiliki t-hitung $(13,704)$ yang besar dari t-tabel $(1,96)$, sehingga $\mathrm{H} 1$ diterima dan $\mathrm{H} 0$ ditolak maka artinya variabel instagram berpengaruh signifikan terhadap minat beli. Sedangkan untuk variabel inovasi produk memiliki t-hitung $(-0,463)$ lebih kecil dari ttabel $(1,96)$ sehingga $\mathrm{H} 2$ ditolak dan $\mathrm{H} 0$ diterima maka artinya variabel inovasi produk tidak berpengaruh signifikan terhadap minat beli. Kemudian variabel citra merek memiliki t-hitung $(0,632)$ lebih kecil dari t-tabel $(1,96)$ sehingga $\mathrm{H} 3$ ditolak dan H0 diterima maka artinya variabel citra merek tidak berpengaruh signifikan terhadap minat beli.

Hasil uji koefisien determinasi menunjukkan bahwa pengaruh variabel instagram, inovasi produk dan citra merek yang diuji secara bersama terhadap minat beli adalah sebesar $66.5 \%$. Hal ini berarti ketiga variabel tersebut terhadap minat beli produk kuliner pada masa pandemi covid 19 ini memberikan kontribusi pengaruh cukup besar sebesar $66.5 \%$ didaerah Jakarta selatan.

\section{Pengujian Hipotesis}

Tabel 1. Distribusi Karakteristik Responden

\begin{tabular}{|l|c|c|}
\hline Demografi & Frekuensi & Persetase (\%) \\
\hline Gender & & \\
\hline Laki-laki & 20 & 20.0 \\
\hline Perempuan & 80 & 80.0 \\
\hline Usia & & \\
\hline 15-20 Tahun & 29 & 29.0 \\
\hline 21-25 Tahun & 53 & 53.0 \\
\hline 26-30 Tahun & 12 & 12.0 \\
\hline > 30 Tahun & 6 & 6.0 \\
\hline Pekerjaan & & \\
\hline Belum Bekerja & 3 & 3.0 \\
\hline Karyawan & 17 & 17.0 \\
\hline Pelajar/Mahasiswa & 73 & 73.0 \\
\hline Wiraswasta & 6 & 6.0 \\
\hline Lain-lain & 1 & 1.0 \\
\hline
\end{tabular}


Sumber: Data diolah, 2021

Tabel 2. Hasil Uji Asumsi Klasik

\begin{tabular}{|l|l|l|l|}
\hline Jenis Pengujian & Cut-off & Hasil & Kesimpulan \\
\hline Normalitas & $>0.05$ & 0.355 & $\begin{array}{l}\text { Memenuhi } \\
\text { Asumsi }\end{array}$ \\
\hline Multikolinearitas & $\begin{array}{l}\text { Tolerance }< \\
0.10 ; \mathrm{VIF}<10\end{array}$ & $\begin{array}{l}\text { Tolerance/VIF } \\
\text { X1_Instragram }=0.995 / \text { VIF }=1.005 \\
\text { X2_Inovasi_Produk=0.622 / VIF }= \\
1.609\end{array}$ & $\begin{array}{l}\text { Memenuhi } \\
\text { Asumsi }\end{array}$ \\
& X3_Citra_Merek $=0.619 /$ VIF $=1.614$ & \\
\hline Heteroskedastisitas & $\begin{array}{l}\text { Tidak terjadi } \\
\text { pola } \\
\text { berkelompok }\end{array}$ & $\begin{array}{l}\text { Hasil distribusi data menyebar } \\
\text { mendekati 0 }\end{array}$ & $\begin{array}{l}\text { Memenuhi } \\
\text { Asumsi }\end{array}$ \\
\hline Autokorelasi & $\begin{array}{l}\text { Alpha 5\%, } \\
\text { DU }<\mathrm{x}<4-\mathrm{DU}\end{array}$ & Durbin-Watson $=2.051$ & $\begin{array}{l}\text { Memenuhi } \\
\text { Asumsi }\end{array}$ \\
\hline
\end{tabular}

Sumber: Data diolah, 2021

Tabel 3. Hasil Analisis Regresi Linier Berganda, Uji t, dan Uji F

\begin{tabular}{|l|c|c|c|c|c|}
\hline \multirow{2}{*}{ Model } & \multicolumn{2}{|c|}{$\begin{array}{c}\text { Unstandardized } \\
\text { Coefficients }\end{array}$} & $\begin{array}{c}\text { Standardized } \\
\text { Coefficients }\end{array}$ & \multirow{2}{*}{ t } & Sig. \\
\cline { 2 - 6 } & B & Std. Error & Beta & & \\
\hline (Constant) & 3.166 & 3.915 & & .809 & .421 \\
\hline X1_Instragram & .428 & .031 & .812 & 13.704 & .000 \\
\hline X2_Inovasi_Produk & -.034 & .074 & -.035 & -.463 & .645 \\
\hline X3_Citra_Merek & .062 & .097 & .047 & .632 & .529 \\
\hline $\mathrm{R}=0.815$ & \multicolumn{5}{|l}{} \\
\hline $\mathrm{R}^{2}=0.665$ & \multicolumn{7}{|l|}{} \\
\hline Uji F-Annova $=$
\end{tabular}

Variabel dependen: Y_Minat_Beli

Sumber: Data diolah, 2021

\section{Pembahasan}

Instagram secara parsial berpengaruh signifikan terhadap minat beli karena di instagram memberi informasi dari sebuah foto, vidio suka berbagi cerita dan chattingan hingga berbagi informasi, hal ini membuat para konsumen merasa nyaman dan percaya terhadap produk melalui akun media sosial Instagram dan mampu meningkatkan percaya diri konsumen dengan cara satu sama lain saling berinteraksi melalui media sosial instagram. Hubungan para pengguna istagram mampu memelihara hubungan yang baru maupun yang sudah terjalin sehingga pengguna merasa lebih dekat dengan perusahaan pengguna media sosial (Habibie et al, 2021, Suparnoto \& Setiobudi, 2020; Hartawan et al, 2021; Untari \& Fajariana, 2018; Hanief \& Jepriana, 2019).

Inovasi produk secara parsial tidak berpengaruh signifikan terhadap minat beli karena dari penelitian menunjukkan bahwa para inovasi produk masih belum optimal dalam meningkatkan minat beli konsumen yang mereka inginkan, sebab inovasi banyak dilakukan oleh para pemilik usaha dimana 
inovasi produknya tidak memiliki keunggulan dan keunikan dari produk lainnya, semua produk yang ditawarkan oleh produsen menurut konsumen sama saja (Wahid \& Puryantoro, 2019; Rachman, 2021; Izhar, 2019)

Citra Merek secara parsial tidak berpengaruh signifikan terhadap minat beli karena minat beli konsumen tidak dapat diukur dengan citra merek yang dimiliki oleh suatu produk, konsumen akan lebih mengutamakan pada kualitas produk tersebut. Selain kualitas produk yang lebih diperhatikan oleh konsumen dari pada citra merek, produk apa saja yang akan dibeli konsumen secara berulang-ulang, ini berarti konsumen tidak akan menjadikan citra merek suatu merek sebagai bahan pertimbangan dalam menentukan pembelian suatu produk (Ambarwati et al, 2015; Bakri \& Saputra, 2019; Geraldine \& Susanti, 2021).

\section{KESIMPULAN DAN SARAN}

Kesimpulan

Sebelum pandemi covid 19 umumnya pelanggan atau calon pembeli lebih memilih produk-produk kuliner dengan berbagai rasa sesuai dengan keinginan mereka. Sehingga hal ini berdampak pada makin berkembangnya produk kuliner atau makin banyak jenis varian dari suatu produk kuliner. Namun pada saat pandemic Covid 19 dan diterapkannya pembatasan aktivitas masyarakat mengurangi aktivitas bertemu langsung dengan pedagang atau usaha kuliner.

Berdasarkan pembahasan diatas maka disimpulkan bahwa pada kondisi saat ini pedagang atas usaha bidang kuliner perlu memanfaatkan fasilitas informasi produk secara detail salah satunya adalah melalui instagram. Dengan instagram pedagang atau usaha kuliner dapat memberikan informasi semenarik dan selengkap mungkin mulai dari proses pembuatan sampai pada pengemasannya. Pengusaha kuliner tidak hanya berfokus pada inovasi produk dan pencitraan merek.

Masyarakat Indonesia khususnya kaum milenial pada saat ini banyak menggunakan instagram dalam mempertimbangkan atau meningkatkan minat beli mereka. Dari penelitian ini menemukan bahwa sebagian besar usia milenial akan berminat beli produk kuliner berdasarkan informasi dari instagram, dibandingkan dengan inovasi suatu produk kuliner dan citra merek produk kuliner di wilayah Jakarta Selatan. Sehingga hal ini juga dapat menjadi perhatian bagi pengusaha kuliner yang berada di daerah lainnya.

\section{Saran}

Berdasarkan pembahasan diatas maka disarankan bagi pedagang atau usaha kuliner yang belum memiliki akun instagram, perlu segera membuat akun istagram selain memperbanyak variasi produknya. Hal ini cukup penting dikarenakan pada saat ini perilaku masyarakat banyak menggunakan peralatan teknologi untuk mencari informasi berbagai produk termasuk produk kuliner di dunia maya salah satunya dalah melalui aplikasi instagram. Tujuannya agar produk kuliner yang dijual oleh pedagang akan dikenal dan akan meningkatkan minat beli di msyarakat khususnya para milenial. Untuk mendukungnya perlu dipelajari bagaimana membuat konten-konten yang menarik sesuai dengan selera masyarakat khususnya kaum milenial.

\section{Daftar Pustaka}

Ambarwati, M., Sunarti., \& Mawardi, M. K. (2015). Pengaruh Citra Merek Terhadap Minat Beli (Survei Pada Mahasiswa Universitas Brawijaya Yang Menggunakan Pasta Gigi Pepsodent). Jurnal Administrasi Bisnis (JAB), 25(1): $1-7$. 
Antonius, I., \& Sugiharto (2013). Pengaruh Strategi Diferensiasi, Citra Merek, Kualitas Produk, Harga Terhadap Keputusan Pembelian Pelanggan di Cincau Station Surabaya. Jurnal Manajemen Pemasaran, 1(2): 1-11.

Bakri, A. N., \& Saputra, I. (2019). Apakah

Citra Merek Dan Pelayanan Memiliki Pengaruh Terhadap Minat Beli Konsumen Pada Kafe Rabbids Kota Palopo?. Dinamis Journal of Islamic Management and Bussines, 2(1): 23-29.

Dachi, A. (2020). Inovasi Produk Terhadap Keputusan Pembelian Dan Dampaknya Terhadap Loyalitas Pelanggan: Studi Pengguna Mobil Toyota Calya di Kota Bogor Dan Bekasi. Jurnal Sosial Humaniora dan Pendidikan, 2(4): 120 129.

Diamond, S. (2015). The Visual Marketing Revolution 20 Kiat Sukses Pemasaran di Media Sosial. Jakarta: Serambi Ilmu Semesta.

Fauziah, N., \& Mubarok, D. A. A. (2019).

Pengaruh Citra Merek Terhadap Minat Beli : Studi Pada Produk Kecantikan. Journal Image, 8(1): 37-44.

Geraldine, Y. M., \& Susanti, A. (2021). Pengaruh Merek, Kualitas Produk, Media Sosial Dan Harga Terhadap Minat Beli Konsumen Pada Produk Brand Wardah. Jurnal Ekonomi dan Manajemen, 3(1): 1-12.

Gifani, A., \& Syahputra. (2017). Pengaruh

Citra Merek Terhadap Keputusan Pembelian Produk Smartphone Oppo Pada Mahasiswa Universitas Telkom. Bisnis dan Iptek, 2(10): 81-94.

Habibie, F. H., Mustika, A., Ratnaningtyas, H., \& Noveti, H. (2021). Promotion of Instagram and Purchase Intention: $\mathrm{A}$ Case of Beverage Business at Covid-19 Pandemic. (TRJ) Tourism Research Journal, 5(1): 78-96.

Hanief, S., \& Jepriana, I. W. (2019).
Pemanfaatan Media Sosial Sebagai Media Promosi Kuliner Sate Lilit dan Ikan Kusamba Bali. Widyabhakti Jurnal Ilmiah Populer, 2(1): 44-48.

Hartawan, E., Liu, D., Handoko, M. R., Evan, G., \& Widjojo, H. (2021). Pengaruh Iklan di Media Sosial Instagram Terhadap Minat Beli Masyarakat Pada ECommerce. Jurnal Ilmiah Manajemen Bisnis dan Inovasi Universitas Sam Ratulangi, 8(1): 217-228.

Izhar, N. R. (2019). Pengaruh Inovasi, Lokasi, Promosi, Harga, \& Produk Terhadap Minat Beli Pelanggan Pada Coffee Shop Kopikumania Samarinda. EJournal Administrasi Bisnis, 7(1): 182194

Lao, Hendrik A.E. (2020). Manajemen Inovasi Dan Penciptaan Nilai Organisasi. Jurnal Humaniora, 1(4): 235-241.

Mayasari, I., Sugeng, N. W., \& Ratnaningtyas, H. (2021). Peran Bauran Pemasaran Terhadap Keputusan Pembelian Generasi Milenial: Studi Jajanan Tradisional. At-Tadbir: Jurnal Ilmiah Manajemen, 5(2): 135-147.

Mustika, A., Hendradewi, S., \& Ratnaningtyas, H. (2021). Halal Label: Is It Important In Determining Buying Interest?. JIMFE (Jurnal Ilmiah Manajemen Fakultas Ekonomi, 7(1): 110.

Nisrina, M. (2015), Bisnis Online Manfaat Media Sosial Dalam Meraup Uang. Yogyakarta: Kobis.

Purwanti, Sarwani, \& Denok Sunarsi. (2020). Pengaruh Inovasi Produk Dan Brand Awareness Terhadap Keputusan Pembelian Konsumen Pada PT. Unilever Indonesia. Inovasi, 7(1): 24-31.

Putra, I. B. P., \& Kusumadewi, N. M. W. (2019). Pengaruh Inovasi Produk Terhadap Niat Pembelian Ulang Dimediasi Oleh Kepuasan Konsumen. EJurnal Manajemen, 8(8): 4983-5006. 
Wahid, F. A., \& Puryantoro. (2019). Analisis Kepuasan Konsumen Terhadap Minat Beli Produk Bunga Melati(Studi Kasus Desa Talkandang, Kecamatan Situbono). Agribios: Jurnal Ilmiah, 17(2): 72-85.

Rachman, T. (2021). Pengaruh Inovasi Produk, Kualitas Produk dan Citra Merek Terhadap Keputusan Pembelian Smartphone ASUS di Bekasi. Jurnal Pelita Ilmu, 15(1): 48-52.

Rehman, F. u., Nawaz, T., Khan, A., \& Hyder, S. (2014). How Advertising Affects the Buying Behaviour of Consumer in Rural Areas: A Case of Pakistan. Academic Research International, 5(4): 405-412

Rizal, A. S., Telagawathi, N. L. W. S., \& Yulianthini, N. N. (2019). Pengaruh Citra Merek Dan Harga Terhadap Loyalitas Pelanggan Sepatu Merek NIKE Di Singaraja Futsal. Prospek: Jurnal Manajemen dan Bisnis, 5(2): 34-40.

Sinurat, E., Mentari, S., Lumanauw, B., \& Roring, F. (2017). Pengaruh Inovasi Produk, Harga, Citra Merek, Dan Kualitas Pelayanan Terhadap Loyalitas Pelanggan Mobil Suzuki Ertiga. Jurnal EMBA, 2(5): 2232-2234.

Sugiyono. (2017). Metode Penelitian Kuantitatif, Kualitatif, dan R\&D. Bandung: Alfabeta, CV.

Suparnoto, R. F., \& Setiobudi, A. (2020). Pengaruh Promosi Media Sosial Instagram Terhadap Minat Beli Produk Havermood. PERFORMA: Jurnal Manajemen dan Start-Up Bisnis, 5(5): 404-412.
Suyaman, D. J., Andriani, E. F., Alifiani, S., Juniar, D., \& Azzahra, F. (2021). Pengaruh Inovasi Produk dan Promosi Penjualan terhadap Minat Beli Sepeda Motor Suzuki Satria F150 (Survei pada Komunitas Suzuki Satria F150 Indonesia). Jurnal Ekonomi \& Ekonomi Syariah, 4(1): 572-587.

Tumbel, A. L., Rate, P. V. (2015). Pengaruh Bauran Pemasaran Terhadap Keputusan Pembelian di Pasar Tradisional (Studi Pada Pasar Tradisonal di Kota Manado). Jurnal LPPM Bidang EkoSosBudKum, 2(20): 60-72.

Untari, D., \& Fajariana, D. E. (2018). Strategi Pemasaran Melalui Media Sosial Instagram (Studi Deskriptif Pada Akun @ Subur_Batik). Widya Cipta Jurnal Sekretari dan Manajemen, 2(2): 271-278.

Widiarta, P. G. K., Mahardika, I. P. D., Nugraha, N. A. S., Tintara, I. D. G. W., \& Yasa, N. N. K. (2020). Peran Inovasi Produk Memediasi Orientasi Teknologi Terhadap Keunggulan Bersaing. E-Jurnal Ekonomi dan Bisnis Universitas Udayana. 9(2): 199-226.

Yanto, E., \& Herman, H. (2020). Pengaruh Promosi Dan Citra Merek Terhadap Loyalitas Pelanggan Pada PT. Tiga Benua. Jurnal EMB: Jurnal Riset Ekonomi, 8(3): 103-112. 